\title{
Quality Education: A Harbinger for Attaining Millennium Development Goals in Nigeria
}

Lucas .B. Ojo (Ph.D.)

\author{
School of Technical Education, Yaba College of Technology, Yaba, Lagos, \\ In affiliation with University of Nigeria, Nsukka \\ Email:lucasojobab@yahoo.com,
}

Alaka Ambali Abayomi (Ph.D.)

The Institute of Chartered Accountants of Nigeria, Victoria Island, Lagos, yomibunmi1972@gmail.com

Odozi, Anuli Faith

Students Affairs Unit (Counselling Department), Yaba College of Technology, Yaba, Lagos Email:anwuliodozi@yahoo.com

\section{Doi:10.5901/mjss.2014.v5n27p861}

\section{Abstract}

Provision of quality education, no doubt, is one of the most important investments that a country can make. Not only does it fulfill people's right to knowledge, it is one of the most powerful ways of accelerating economic growth, reducing poverty, unemployment, child mortality and improves maternal health. The Millennium Development Goals (MDGS) are laudable and very worthy to be pursued so as to catalyze the needed growth and development we so crave for in Nigeria. It is obvious that the attainment of these goals can only materialize through giving the citizenry the appropriate sound quality education. The paper focuses on the components of quality framework, MDGS and Nigeria situation. To actualize the MDGS, the paper discussed some strategies for attaining the MDGS such as equal access to quality education, technology transfer, teachers' training and development, better quality teaching materials etc. The paper recommended that teaching and learning right away from primary schools to university levels should enhance MDGS related skills, knowledge and behaviour. Also the federal government should harmonies policies and procedures already in existing towards realizing the UBE, EFA and Millennium Development Goals.

Keywords: Quality Education, Millennium Development Goals (MDGS), Universal Basic Education (UBE), Education For All (EFA).

\section{Introduction}

Achieving the objectives set by the international community in the field of education is a permanent challenge for most African countries. The education sector is in a particularly different situation in Sub-Saharan African where poverty and its consequences, including hunger, illiteracy, uncontrolled population growth, a deterioration environment, and pandemics such as HIVIAIDS, Malaria and TB are part of people's daily lives. It is generally held that education (i.e. formal schooling) is positively associated with human development, this has long been seen as an engine to drive economic growth, create a productive labour force, improve health and controlled fertility. Educations' expected role in nation building is also reflected in the way many developing countries, once liberated from colonial rule, pledged to provide quality basic education for the attainment of Millennium Development Goals (MDGS).

Globally, the reform of management in the educational sector is increasingly seen as an essential component of enhancing relevance and providing social justice. In this wise, the educational system at any level must therefore be qualitative in order to make education capable of playing the part of enhancing socio-economic development, reducing inequality and encouraging economic competitiveness. The indicators of quality must now become those that can promote advancement of knowledge and mastery of skills as well as prepare the learners for leading a meaningful life in the world (Ayodele, 2004).

It has been empirically proved and universally acknowledged that unless the citizen of a nation are well educated and appropriately trained the achievements of rapid economic and social development of such a nation cannot be guaranteed (Odekunle and Okuwa, 2012). Conceptualizing education in its right perspectives by inculcating sound quality 
education programmes would bring in positive changes in the economics development of a nation. Consequently, economics development depends on the qualitative workforce and this qualitative workforce can be acquired by development professionals, social and communication skills through quality education which is the basis for the concept of human development (Qurratulain, 2006). According to G8 summit (2006), economics and social prosperity in the $21^{\text {st }}$ century depend on the ability of nations to educate all members of their societies to be prepared to thrive in a rapidly changing world. Recent development within the globe has further reminded us that education is beyond a tool for development but that it has now taken the position of a 'Vaccine' that could be used to prevent the spread of disease, reduce child mortality, eradication of poverty and hunger and to promote gender equality and empowerment of women. From all indication, quality education is a suitable instrument to achieve the Millennium Development Goals (MDGS) in Nigeria $(U N O, 2006)$.

\section{Review of Related Literature}

\subsection{Conceptualizing Quality Education}

The concept of quality education has been given various interpretations to the extent that a common definition is farfetched. Quality education is not an easy concept to qualify. At times when we are discussing a quality education for all our learners it is important to take time to understand this concept. According to the Education For All: Global Monitoring Report (2005) the quality imperative (EFA. GMR), two principles characterize most attempt to define quality in education; the first indentifies learner's cognitive development as the major explicit objective of all education systems. The second emphasis education's roles in promoting values and attitudes of responsible citizenship and in nurturing creative and emotional development. Quality determines how much and how well children learn and the extent to which their education translates into a range of personal, social and developmental benefits.

Kagia (2005) defined quality education as that education which ensures not only the acquisition of knowledge but the application of whatever is learnt to real life situation. Goals 6 of the Dakar Framework for Action (DFA,2000) emphasizes the need of a stimulatory pedagogy, as the reaching and learning process that brings the curriculum to life, that determines what happens in the classroom and subsequently the quality of the learning outcome. Ojo (2012) sees quality education to be that which is relevant and adapted to the need of the community in a complex and integrated world of living in a technological age where standards of housing, health, clothing, transportation, information, industrialization etc, are set. According to Stephension (2003) quality education should meet the following objectives.

- Help learners to acquire the critical skills for peaceful negotiation, problem solving, understanding human right, universal values and domestics practices required for living with others.

- Equip learners with values, knowledge, competencies and behavior which are relevant to the demand of modern world

- Contribute to sustainable human development to the quality of life of the individual and society for peace and security.

- Ensure that every individual has the opportunity to develop his or her full potentials.

Quality education has the power to transform societies in a single generation, provide children with their protection they need from the hazard of poverty, labour exploitation and disease and give them the knowledge, skills and confidence to reach their full potential.

\subsection{Components of a Quality Framework.}

The following components which have reached different degree of emphasis from different authors have been identified as a useful analytical framework for this concept (Ojo, 2012).

* Effectiveness

* Efficiency

* Equality

* Relevance

* Suitability.

Effectiveness: This is a degree to which the objectives of an education system are being achieved both externally and internally. External effectiveness refers to the degree to which the education system meets the needs of individuals and society as a whole while internal effectiveness applied to the functioning of institutions which concerned with outputs 
of education.

Efficiency: Refers to the ratio of outputs to inputs. That is, efficiency measures the extent to which we make best use of inputs to achieve our educational goals. External efficiency refers to the ratio of monetary outputs to monetary inputs, while internal efficiency looks at the ratio of non-monetary outputs to monetary inputs.

Equality: Equality as a component of educational quality commonly arises from a position that takes a quality education as a human right (UNESCO, 2000). This is turn builds on the relationship of education to development models based on human development and poverty reduction, social cohesion, social diversity, peace etc (Michaelowa, 2001). A key element in the discussion of equality in education is the identification of groups that are disadvantaged in terms of access and achievement (e.g. girls, the disabled and the poorest).

Relevance: This refers to the extent to which education can be used by the society to realize its dreams as well as contribute to recipient's aspiration in life. A key challenge for countries like Nigeria in keeping pace with the changes in the fast growing world of technology and adapting the technology to suit our purpose. A synthesis of various source bring us to a brief categorization of the educational quality concerns of different categories of nation, as illustrated in table 1

Table 1 - Priorities in Education Quality by Level of National Development

\begin{tabular}{|l|l|}
\hline State & Emphasis within the Quality Debate \\
\hline Post-conflict newly founded state & Subsistence, security trust, school system, curriculum. \\
\hline Low income countries & Access livelihood (coping lasting, flexibility). Primary schools. \\
\hline Middle income countries & Continuation-secondary schools, disadvantaged groups. \\
\hline OECD countries & Competences, responsibility, life long, learning, sustainability. \\
\hline
\end{tabular}

Sources: Synthesized from McDowell (2002). Michaelowa (2001); Akkari (2005); Romano (2002); Kagia (2005).

Sustainability: This is the fifth element in our framework for educational quality. Its means, the ability to meet the needs of the present without compromising the ability of future generation to meet their own needs. From this perspective, quality education emerge in the context of the obligation to establish and sustain the conditions for each and every individual, irrespective of gender, ethnicity, race or regional location to achieve valued outcome (UN 2003).

\section{Understanding Millennium Development Goals in Nigeria}

The Millennium Development Goals (MDGS) originated from the Millennium Declaration product by the United Nations. The Declaration asserts that every individual has the right to dignity, freedom, equality, a basis standard of living that includes freedom from hunger and violence and encourages tolerance and solidarity. The MDGS were made to operationalize these ideas by setting targets and indicators for poverty reduction in order to achieve the right set forth in the declaration on a set fifteen-year timeline. The aim of the MDGS is to encourage development by improving social and economic conditions in the world's poorest countries. The MDGS call for a global partnership to address the most critical issues of our time (Mfam, 2009)

The Millennium Development Goals (MDGS) are eight international development goals that were officially established following the Millennium Summit of the United Nation in 2000, following the adoption of the United Nations Millennium Declaration. All 193 United Nations members and at least 23 International Organizations have agreed to achieve these goals by the year 2015. The goals are:

* Evaluating extreme poverty and hunger

* Achieving universal primary education

* Promoting gender equality and empowering women.

* Reducing child mortality rates.

* Combating HIVIAIDS, malaria and other disease

* Ensuring environmental suitability and

* Developing a global partnership for development.

Aremu (2008) observes that, the UN declaration stormed the world with a sort of refreshing atmosphere of hope when world leaders adopted the MDGS which besides embracing most of the IDTS, included poverty dimension connected to hunger, water diseases, HIVIAIDS, orphans and urban poverty among others. Each of the goals has specific stated target and dates for achieving those targets. To accelerate progress, the G8 finance ministers agreed in June 2005 to provide enough funds to the World Bank, the International Monetary Fund (IMF), and the African 
Development Bank (ADB) to cancel an additional $\$ 40$ to $\$ 55$ billion in debt owned by members of heavily indebted poor countries (HIPC) to allow impoverished countries to re-channel the resources saved from the forgiven debt to social programs for improving health and education and for alleviation poverty.

Barely four years after the Millennium Declaration, many countries have made tremendous progress toward achieving the Millennium Development Goals (MDGS), but many lag behind. Progress has been uneven. To this end, Nigeria came up with the National Economic Empowerment and Development Strategy (NEEDS) which was launched on May 29, 2004 as part of the efforts put in place to meet the MDGS target in 2015. According to World Bank (2004) the target of poverty, education and partnership goals for Africa are:

(a) Poverty: This means lifting people out of extreme poverty by providing them with the basic things they need to live a descent life, nutritious foods, cloths, clean water, a home and health care. The goal is to reduce the proportion of people living in extreme poverty in developing countries and the proportion of malnourished children by at least one half between 1990 and 2015. In Africa the goals is to reduce poverty from a level of $48.4 \%$ to $22 \%$ by 2013 , while in malnutrition, the proportion of children under age five (5) who are underweight to be reduced from a level of $28.5 \%$ to $13.3 \%$ by 2015 .

(b) Education: The aims of goals 2 are to make sure that children (male and female) are able to complete a full course of primary schools by 2015 . The goal here is that there should be universal primary education in all countries by 2015. The African primary school involvement should be increased from $60 \%$ in 1999 to $10 \%$ by 2015.

(c) Gender equality: This goals 3 means guaranteeing that women have equal opportunities to make their lives and the lives of their families better. The goal is to eliminate gender disparity and secondary education preferably by 2015, and in all levels of education not later than 2015.

(d) HIVIAID, Malaria and Other Disease: The goals 6 aims to stop, and finally reverse the spread of HIV/Aids, malaria and other deadly disease by 2015 .

(e) Partnership: Collaboration between rich and poor counties is the key to achieving Goal 8. According to Mfam and Awoniyi (2008) there are several goals under global partnership for development which are: (a) address the spread needs of the least developed countries, (b) in cooperation with developing countries, and implement strategies for decent and productive work for youth, and (c) in cooperation with the private sector, make available the benefits of new technologies, especially information and communications, etc.

In other to achieve the MDGS, a UN conference in September 2012 reviewed progress to date and concluded with the adopted of a global plan to achieve the eight anti-poverty goals by their 2015 target date.

Table 2: MDGS and Human Development Index 2013 in Nigeria

\begin{tabular}{|c|l|l|}
\hline S/N & Human Development Index & Ranking 153 \\
\hline 1 & Health & Life expectancy at birth (years) 52.3 \\
\hline & Education & Mean years of schooling (of adults)(years) 5.2 \\
\hline 3 & Income & $\begin{array}{l}\text { GNI per capita in PPP (constant 2005 international \$) (constant } 2005 \\
\text { international \$) 2,102 }\end{array}$ \\
\hline 4 & Inequality & Inequality-adjusted HDI value 0.276 \\
\hline 5 & Poverty & MPl:Multidimensional poverty index (\%) 0.310 \\
\hline 6 & Gender & Gll: Gender inequality index, value n.a \\
\hline 7 & Sustainability & Carbon dioxide emission per capita (tone) 0.6 \\
\hline 8 & Demography & Population, total both sexes (thousands) $166,629.4$ \\
\hline 9 & Composite indices & Non-income HDI value 0.482 \\
\hline 10 & Innovation and technology & Fixed and mobile telephone subscribers per 100 people (per 100 people) 55.8 \\
\hline 11 & Trade, economy and income & Income index 0.450 \\
\hline
\end{tabular}

Source: World Bank (Human Development Report) 2013

Nigeria has not being doing well in all her effort to achieve Millennium Development Goal (MDGS) before 2015. Table 2 clearly indicated a rank of 153 out 187 counties with comparable data by the United Nation Human Development Report of 2012. Life expectancy at birth (years) is put at 52.3 only 1.9 percent of the nation's budget is expanded on health while the mean years of schooling (of admits) (years) is put at 5.2. The income index is 0.450 . It is estimated that about 85million people live on less than a dollar a day and about 70million Nigeria lives or less than 2 dollar per day. The incidence of poverty is higher even compared to countries in the West African region like Ghana, Ivory Coast, etc. 
The agency in its 2013 Human Development Index (HDI) report listed Angola, Burundi, The Democratic Republic of the Congo, Ethiopia, Liberia, Mali, Mozambique, Niger, Rwanda, Sierra Leone and Tanzania as among the African countries that made the greatest strides in HDI improvement since 2000 to date.

On funding of education, Nigeria is yet to comply with UNESCO's recommendation that $26 \%$ of annual budget be spent on education. Nigeria spends less than 9\% of her annual budget on education on yearly basis from 1980-2013. Countries like Botswana spends 19.0\% Swaziland 24.6\% ; Lesotho, 17.0; South Africa 25.8\%; Cote d' Ivoire, 30.0\%; Burkina Faso 16.8\%; Ghana 31\%; Kenya 23.0\%; Uganda, 27\%;, Tunisia 17.0\%; and Morocco, 17.7\%. As Nigeria was ranked amongst countries with low development index, the latest ranking of world universities released by the Times Higher Education (THE) for 2012-2013 has indicated that no Nigerian university made the list of the best 400 in the world. According to the report the top four universities in Africa all came from South Africa, with the University of Cape Town which ranks 113 in the world with 55.8 as number one on the continent. The University of Witwatersrand, Stellenbosch and Kwazulu-Natal, all in South Africa, came second, third and fourth with 226, 251 and 351 in overall scores respectively. [Time Higher Education, 2012].

On economic, the economic growth has neither cut poverty nor created necessary jobs. The unemployment rate in 2010 was 21.1\%; in 2011 it was $23.9 \%$ and in 2012 it went up to $37.7 \%$. This has further driven away the country from reducing poverty by 2015 . Country like Norway which produces about the same amount of crude oil as Nigeria is among the richest countries in the world with one of the highest standard of living while Nigeria is among the poorest as less than $27 \%$ of people have access to portable water (Abubakar, 2012).

\section{Quality Education and MDGS in Nigeria}

The major focus of education is the development of the individual vis-à-vis the society. It is also a major tool for the quick transformation of any nation. The National Policy on Education (2004) has rightly described education as instrument per excellence. In recognizing this crucial role of education to human development and the Millennium Development Goals (MDGS, 2000), have led to a greater attention being paid to educational advancement. In view of this the Federal Government introduced the National Economical Empowerment and Development Strategy (NEEDS, 2004) which emphasis the centrality of education to national development. Mfam and Awoniyi (2008) noted that in Nigeria NEEDS provides more realistic focus of the millennium goals and therefore serves as the most appropriate perspective from which to discuss MDGS.

A suggested aim for quality education is given as building human capacity not only for employability, but for broader lifelong learning as well as for adaptive and coping livelihood strategies in a fast moving and complicated world. To eradicate extreme poverty and hunger under the MDGS, the Federal Government of Nigeria has clearly stated in the National Policy on Education (FNG, 2004) to give training and impact the necessary skills to individual who shall be self reliant economically. One of the national aims and objectives of education (NPE, 2004) is the acquisition of appropriate skills abilities and competences both mental and physical as equipment for the individual to live in and contribute to the development of his society. A total of 17,684 new cases of children with Severe Acute Malnutrition (SAM) have been reported and treated in October 2012. While the cumulative number of children as at October 2012 stands at 179,453. About $84 \%$ of cholera cases are also reported in Zamfara, Kaduna and Gombe States. It must be noted that one of the source of poverty is lack of basic services including education. Hence, education can reduce poverty by providing everyone with chances and opportunities to create a better life for themselves. In a situation where people are given right education there is tendency for poverty to be alleviated. According to Mfam (2009), a self reliant person has the potential to create employment thereby sharing in the poverty burden of Nigeria.

The United Nations Organization (UNO, 2001) at a general special season identified education as a "social vaccine" for the prevention of HIVIAIDS In the absence of any known vaccine. To achieve the MDGS of combating HIVIAIDS malaria and other related disease, it is only through sound quality education that awareness of and the sensitivity about the epidemic can be spread amongst the people. This would assist students to understand better and accept that all people must accept responsibility for the prevention of HIV transmission and adequate provision of care and support. For those infected and affected. Since serious campaign against HIVIAIDS started Nigeria, has began to reverse the spread of the HIVIAIDS and other major diseases.

The status of HIVIAIDS epidermis in Nigeria is precarious. With an estimated population of $162,265,000$, Nigeria is the most populated country in Sub-Saharan Africa, a region which carries the globe's heaviest burden of HIVIAIDS. 
Table 3: Epidemiology of HIV in Nigeria: key facts

\begin{tabular}{|l|c|c|}
\hline & $\mathbf{2 0 0 8}$ & $\mathbf{2 0 1 2}$ \\
\hline National Median HIV Prevalence & $4.6 \%$ & $4.1 \%$ \\
\hline Estimated number of PLWHIV & $2,980,000$ & $3,459,363$ \\
\hline Annual AIDS Death & 192,000 & 217,148 \\
\hline Number requiring antiretroviral therapy & 857,455 & $1,449,166$ \\
\hline New HIV infections & 336,379 & 388,864 \\
\hline Total number of AIDs orphans & $2,175,760$ & $2,193,745$ \\
\hline
\end{tabular}

Sources: Federal Republic of Nigeria Global AIDS Response Country Progress Report (GARPR) 2012.

The most recent HIV seroprevalence figure represents about 3.5milion people infected with HIV, ranking Nigeria third among the countries with the highest HIVIAIDS burden in the world nest only to India and South Africa. The annual AIDS death has increase from 192,000 in 2008 to 217,148 in 2012. According to the Director-General of the National Agency for the control of AIDS (NACA) Professor John Idoko, (2013), confirmed that Nigeria carries 30 per cent of the HIVIAIDS burden in the World. He suggested that if the country can address the problems, it has completely addressed the issue in the World. He also reiterated that 70 per cent of the 210,000 children born with HIV in the World are Nigerians; he expressed regret that if 70,000 children born with HIV positive were not given adequate treatment they would not see their fifth birthday. The driver of HIV epidemic in Nigeria include low personal risk perception, multiple concurrent sexual partnership, poor quality health care services, chronic and debilitating poverty, lack of quality education and etc.

The third goals of MDGS is to promote gender equality and empowering women Abimiku and Duktur (2008) observed that inadequate education is one of the problems facing Nigeria women and this affects their empowerment. One of the national objectives enunciated under the country's second development plan is to provide a land of bright and full opportunities for all citizens (FGN, 2004). Education, especially Technical and Vocational Education have adequately provided equal opportunities for the boys and girls to be self -reliance and employment generation instead of employment seekers and also to contribute maximally to the development of Nigeria. Hence equally education must be provided at all levels. This would invariably remove discrimination against women and elimination of all forms of violence against women and the girl child.

Achieving Universal Primary Basic Education is one of the formidable goals of MDGS. Quality education vastly increase the productivity and potential of individuals and by extension the society of which they are part. The target of Universal Basic Education with regard to Millennium Development Goals (MDGS) is that before the year 2015, every Nigerian under the programme whatever the age, sex, education and disability will be able to read, write, count and think and the poor will have been educated out of their poverty. One of the objectives of Universal Basic Education is to ensure the acquisition of the appropriate levels of literacy, numeracy, manipulative and life skills as well as the ethical, moral and civic needed for laying the foundation for life-long learning. At the end of nine (9) years of continuous education, every child should acquire appropriate and, relevant skills and values and be employable with a view to contribute his or her quota to National Development.

In achieving these laudable objectives the federal government outlined implementation guideline to facilitate successes achievement of the UBE programme by providing infrastructural facilities embarking on public establishment campaign and social mobilization for full community involvement; enriching curricula, and by establishing Universal Basic Education Commission on $7^{\text {th }}$ October 2004. According to section $18^{\text {th }}$ of the constitution on UBE "the government shall eradicate literacy" and to this end government shall as and when practicable provide.

a. Free, compulsory and universal primary education

b. Free secondary education

c. Free university education

d. Free adult literacy programmes

The Universal Basic Education (UBE) programmes which have an operational relationship with EFA goals was designed to addressing fundamental issues that border on the structural functioning of the educational system toward ensuring quality education, modernization and quality of life.

\section{Strategies for Achieving Millennium Development Goals (MDGS) In Nigeria}

In this discourse, various efforts have been made by the collective interest of national development as enshrined in the 
various international commitments. Barely less than three years to 2015, the gaps between achieving the MDGS and the present situation in Nigeria now is just too wide. Below are some policies and strategies needed for achieving millennium development goals in Nigeria.

Access to quality education need to increase: A nation's education system must guarantee unhindered access for all citizens at all levels (Odimegwu, 2005). Any nation which will achieve the objectives of EFA must adopt the principle of diversity in educational provision, this implies that education will be provided for all citizens through formal and non-formal modes because of the diverse background and needs of the potential beneficiaries (Sarumi, 2008). More children need to be enrolled in schools and more adults enrolled in formal or non-formal programmes, and the quality of education need to improve. According to Akinwunmi (2007) it is evident that the quality of the country's primary education is threatened. Although the policy document indicates government commitment to providing quality education, the country appears to be lagging behind in achieving the expected quality of education.

Teacher's Training and Development: Education is a progress of developing a group or an individual towards the acquisition of specific values, attitude, skills and knowledge. The roles of teachers in impacting knowledge cannot be over emphasized, "No educational system can rise above the quality of teachers in the system". The teachers are to be encouraged to undergo training and retraining in order for them to be able to impact permanent literacy and numeracy and some useful communication skills to their learner's right from UBE to the university level. It is an axiom that the provision of quality education and training in a nation is a tool for escaping from poverty to prosperity. This suggests that the greater the access to qualitative education and training, the lesser the poverty experience in the nation (Bankole, 2005).

Better Quality Teaching Material: To enhance proper teaching and learning process and for basic education to achieve its set goals, there is need to put certain educational materials, equipment and facilities in place. Library and laboratories should be well equipped and relevant teaching aids should be made available to teacher.

Technology Transfer: The importance of education in human development and the process of modernization are unquestionable. The federal government should embark on vigorous technology transfer in the areas of vocational, technical and entrepreneurial education from other developed countries of the world. In this case, new techniques and innovation will increase investment, production and increasing number of women in the work force. One of the cardinal objectives of technical, vocational and entrepreneurship education is to give training and impact the necessary skills to individual who shall be self-reliant economically. Self reliance reduces unemployment and creates opportunities for employment thereby reduces drastically poverty in the land.

The commitment to achieve MDGS through provision of sound and quality education requires a holistic synergy on the part of government who provides adequate funding from primary schools to university levels. The government should encourage private participation in the delivery of quality education in Nigeria

\section{Conclusion}

The Millennium Development Goals (MDGS) are laudable and worthy to be pursued so as to catalyze the needed growth and development, reduces extreme poverty, decrease in cost of living etc. The achievement of these goals can only be materializing through giving the citizenry the appropriate quality education. According to Udele (2009), a community where knowledge is not allowed to grow, that community remains largely elemental and primitive in the technology age. Enough efforts have not been made toward the realization of the Education For All as well as attaining the Millennium Development Goals in 2015. Nigeria has laid a sound foundation through the introduction of Universal Basic Education ((UBE) programme and the development of the National Empowerment Economic and Development Strategies (NEEDS), more still need to be done especially in pooling all available resources together to provide quality education for our people. A society bedeviled with huge illiteracy population and half backed is bound to remain underdeveloped.

\section{Recommendations}

Based on the conclusion, the following recommendations are proffered.

* Teaching and learning right away from primary schools to university level should enhance MDGS related skills, knowledge and behavior. Issues on child mortality and improving girls' empowerment should be assisted by curricula on cleanliness basic sanitation and measures to minimize contagious disease, HIV and AIDS.

* A focus on equality needs to be at the centre of strategies to meet all MDGS. There should be planning for the provision of basic services. Primary education needs to focus more forcefully than in the past on those specific 
characteristics that can limit the ability of providing basic and compulsory education to all citizenry. As the nation move more closer toward the MDGS, all anti-poverty programmes need to be more sharply focused and disaggregated e.g. National Poverty Eradication Programme (NAPEP).

* The new educational policy of nine (9) years basic education should be allowed to function in view of the fact that it will catch our children young and prepare them for employment.

* Adequate staffing of educational institutions is prerequisites to quality education, as no educational system can rise above the level of its teachers. Obanya (2002) asserted that many laudable educational initiatives have failed mainly because they did not take sufficient account of the teachers' factor. As nation builders, the selection of teachers for appointment should be done meticulously so as to prevent incompetence in service delivery.

* To provide quality education at all levels, the federal government should provide adequately funding and adhere strictly to UNESCO's recommendations on budgeting for education.

* Nigeria's technological and scientific base should be strengthened by re-engineering technical, vocational and entrepreneurial education to meet the economy's manpower needs and to foster self-reliance and employment generation.

* Harmonization of policies and procedures already in existence towards realizing UBE, EFA and MGDS' Agenda.

\section{References}

Abimiku, .C and Duktur, S.L (2008). Promoting Gender Equality and Women Empowerment in Nigeria:The Role of Business Education. Reading in Business Education, $72-78$

Abubakar, M.B (2012). Millennium Development Goals: The Nigeria situation. Kogi Polytechnic, Lokoja.

Akinwunmi, J.F (2007). The Demand for University Graduate and Employees' Assessment of Graduate's Skills in Nigeria "Deft Ibadan NISER"

Aremu, A. (2008). MDGS: Pathway to Sustainable Development. In Abdulsami, Z (Ed). The law maker 9 (186). 50

Ayodeji, G.S (2004). Education and Development: A paper presented at a Training Workmanship Organized by Manpower Development Department. NISER, Ibadan.

Dakar Framework for Action (2000). Education for all: Meeting our Collective Commitment World Education Form 2000.

EFA: Global Monitoring Report Team (2005) Summary Report on EFA: Is the World on Track? Paris (UNESCO)

Federal Government of Nigeria (2004). National Policy on Education. (4th education). Lagos NERDA Press.

G.8 summit (2006). Education for Innovative Societies in the 21st Century, Minister of Education of G8, Petersburg, Russia.

Idoko, J. (2013, April 18). Global Fund Increases Funding For HiVIAIDS in Nigeria. This Day Live

Kagia, R (2005). Quality Education for all Young People: Challenges Trends and Priorities, Prospects. 35 5-12

Mfam, K.T (2009). Vocational and Technical Education: A Panacea for Achieving the Millennium Development Goals in Nigeria. The Voice of Teachers, 1:1, 10-15.

Mfam, K.T and Awoniyl, B.R (2008). Business Education as a Veritable Tool for Achieving Millennium Development Goals in Nigeria. Being Paper Presented at the $2^{\text {nd }}$ National Conference and Exhibition on Vocational Technical Education: A Veritable Tools for Achieving Millennium Development Goals Held at Federal College of Education, Kontagora Niger State, May 27-31.

Michaelowa, K (2001). Primary Education Quality in Francophone Sub-Saharan Africa: Determinants of Learning Achieving and Efficiency Considerations. World Development 29; 101:1699-1716.

Obanya, P (2002). Revitalizing Education in Africa. Ibadan; Print marks

Obanya, P (2003). Reading Nigeria's Millennium Education Dream - The UBE, Ibadan: Millennium.

Odimegwu, F.B.O (2005). Mentors the Challenges of Human Capital Development. The case for Reforms in our Educational Policies and Systems. The $34^{\text {th }}$ convocation lecture, University of Nigeria, Nsukka.

Ojo, L.B (2012). Educational Administration Theory and Practice. Blue sign publications Ltd, Lagos

Olukolade, $O$ and Okuwa O (2012). Enhancing Quality Basic Education for the Attainment of Millennium Development Goals in Nigeria: Suggested Policy Intervention. Journal of Emerging Trends in Educational Research and Policy Studies (JETERADS), 3 CD: 9298.

Qurratulain, A.(2006). Literacy and Economic Development. Retrieved from http:/qurratulain.wordpress.com / 28/3.13/ Literacy -andeconomic.

Sarumi, A.(2008). Millennium Development Goals and the Challenges of National Development in Nigeria. Essays in Honour of Professor Michael Omolewa. Spectrum Books Ltd, Ibadan

Stephenson, D.B. (2003). Culture in Education and Development: Principle Practice and Policy, Oxford, Symposium.

Time Higher Education (2012). Nigerian Varsities missing from Top 400 Rankings. Retrieved from http://www.vanguardngr .com/2012/10/8.

Udele, M.E (2009). Science and Technology Education and the Achievement of the Millennium Development Goals (MDGS). The Voice 
of Teacher, 1:2

UNESCO, (2009).EFA Global Monitoring Report 2009. Overcoming Inequality-Why Government Matters .Paris.

UNICEF, (2004). Girls HIVIAIDS and Education. New York

United Nation Human Development Index (2012). Trend 2005-Present

United Nation's (2000), "Literacy for All: A Renewed Vision for A Ten Year Global Action Plan" Adult Education and Development Bonn 11Z/DVV, 55, 20-25.

World Bank, (2004). World Development Report 2005: A Better Investment Climate for Everyone. New York: Oxford University Press. World Bank (2007). Global Monetary Report, July .Washington Dc. World Bank 